http://ejournal.uhn.ac.id/index.php/opinion

\title{
IMPLEMENTASI DANA DESA SESUAI UNDANG-UNDANG NOMOR 6 TAHUN 2014 (STUDI KASUS DESA LOBUSIREGAR II KECAMATAN SIBORONG-BORONG KABUPATEN TAPANULI UTARA)
}

\author{
Rinsofat Naibaho ${ }^{1}$, Hisar Siregar ${ }^{2}$, Tri Dennis Boy Silitonga ${ }^{3}$ \\ ${ }^{1}$ Program Studi Ilmu Hukum \\ Universitas HKBP Nommensen, Medan-Sumatera Utara-Indonesia \\ e-mail: rinsofatnaibaho@uhn.ac.id
}

\begin{abstract}
The presence of the Law on Villages, namely Law No.6 of 2014 strengthens the status of the Village as a community government as well as a Village power to build infrastructure and prosper the Village community. Villages receive transfer funds from the regions in the form of Village Fund Allocation (ADD). This research was conducted in Lobusiregar II Village, Siborongborong District, North Tapanuli Regency. This study aims to analyze village financial management in managing the Village Fund Allocation. This type of research is a juridicalemipirical legal research with a descriptive analysis approach. This research was conducted using documentation techniques and interviews with parties involved in ADD management. The results of the description are obtained through the analysis of Permendagri No. 113 of 2014 by comparing the realization in the field.
\end{abstract}

Keywords: Village Fund Allocation, Village Financial Management

\begin{abstract}
Abstrak
Kehadiran undang-undang tentang Desa yaitu Undang-Undang No.6 Tahun 2014 memperkuat status Desa sebagai pemerintahan masyarakat sekaligus sebagai kekuatan Desa untuk membangun infrastruktur serta mensejahterakan masyarakat Desa. Desa mendapatkan dana transfer dari daerah berupa Alokasi Dana Desa (ADD). Penelitian ini dilaksanakan di Desa Lobusiregar II, Kecamatan Siborongborong, Kabupaten Tapanuli Utara. Penelitian ini bertujuan untuk menganalisis pengelolaan keuangan Desa dalam pengelolaan Alokasi Dana Desa. Jenis penelitian ini adalah penelitian hukum yuridis-emipiris dengan pendekatan analisis deskriptif. Penelitian ini dilakukan dengan menggunakan tekhnik dokumentasi dan wawancara dengan pihak-pihak yang terlibat dalam pengelolaan ADD. Hasil deskripsi didapat melalui analisa Permendagri No. 113 Tahun 2014 dengan membandingkan realisasi di lapangan. Kata kunci: Alokasi Dana Desa, Pengelolaan Keuangan Desa
\end{abstract}

\section{A. Pendahuluan}

Desa merupakan unsur yang penting di dalam Negara Kesatuan Republik Indonesia (NKRI) karena Desa merupakan cikal bakal terbentuknya masyarakat politik dan pemerintahan di Indonesia, keadaan tersebut tertuang pada pasal 18 Undang-Undang Dasar 1945 bahwa pembagian daerah atas daerah besar dan kecil, dengan bentuk susunan pemerintahannya ditetapkan ke dalam undang-undang dengan memandang dan mengingat dasar permusyawaratan dalam sidang pemerintahan negara dan hak-hak asal-usul dalam daerah yang bersifat istimewa.

Desa sudah ada sebelum Hindia Belanda masuk ke kesatuan perkampungan, kerajaankerajaan dan malah republik-republik. Republik-republik yang dimaksud adalah suatu pemerintahan demokrasi yang mementingkan kesejahteraan rakyat yang bersifat asli dan 
otonom berdasarkan adat istiadat dan sistem nilai budaya masyarakat setempat".

Kebijakan otonomi daerah memberikan hak, wewenang, dan kewajiban daerah otonom untuk mengatur dan mengurus sendiri urusan pemerintahan dan kepentingan masyarakat setempat sesuai dengan peraturan perundang-undangan. Dalam pelaksanaan otonomi daerah, kewenangan daerah diperbesar mencakup kewenangan dalam seluruh bidang pemerintahan, kecuali bidang politik luar negeri, pertahanan kemanan, peradilan, moneter dan fiskal, agama, serta kewenangan bidang lain. Kewenangan bidang lain yang dimaksud yaitu meliputi kebijakan perencanaan nasional dan pengendalian pembangunan nasional secara makro, dana perimbangan keuangan, sistem administrasi negara dan lembaga perekonomian negara, pembinaan dan pemberdayaan sumber daya alam serta tekhnologi tinggi yang strategis, konservasi, dan standarisasi nasional. Otonomi daerah harus dimanfaatkan dengan baik oleh pemerintah daerah untuk membuktikan kemampuannya dalam melaksanakan kewenangannya.

Meskipun kebijakan otonomi daerah dititik beratkan pada pemerintah kabupaten/kota, namun secara langsung harus bersentuhan dengan level pemerintahan ditingkat yang paling bawah, yaitu Desa. Berdasarkan UU NO 6 Tahun 2014 yang dimaksud dengan Desa adalah kesatuan masyarakat hukum yang memiliki batas wilayah yang berwenang untuk mengatur dan mengurus urusan pemerintahan, kepentingan masyarakat setempat berdasarkan prakarasa masyarakat, hak asal-usul, dan/atau hak tradisional yang diakui dan dihormati dalam sistem pemerintahan Negara Kesatuan Republik Indonesia. Sebagaimana yang diamanatkan dalam UU No. 6 Tahun 2014 tentang Desa, tugas penataan Desa serta pemantauan dan pengawasan pembangunan Desa diemban secara bersama-sama oleh pemerintah pusat, pemerintah provinsi dan pemerintah kabupaten/kota. Desa memiliki kewenangan untuk mengatur dan mengurus urusan pemerintahannya sendiri sesuai perundangan.

Pengelolaan keuangan Desa adalah keseluruhan kegiatan yang meliputi perencanaan, pelaksanaan, penatusahaan, pelaporan dan pertanggungjawaban keuangan Desa. Pengelolaan keuangan yang dimaksud adalah pengelolaan Anggaran Pendapatan dan Belanja Desa (APBDes) untuk mendukung dan menjalankan program-progam kerja pemerintah Desa yang telah direncanakan. APBDes adalah rencana keuangan tahunan pemerintah Desa. Salah satu komponen yang ada dalam APBDes adalah Alokasi Dana Desa (ADD). Pengelolaan keuangan Desa merupakan salah satu bentuk kewenangan yang diberikan kepada pemerintah Desa untuk mendorong tata kelola pemerintahan yang baik (good governance). Menurut UNDP (1997), pemerintahan yang baik memiliki karakteristik akuntabilitas, transparansi, partisipasi, tertib hukum, responsif, konsensus, adil, efisiensi dan efektivitas serta memiliki visi strategis. ${ }^{5}$ Good governance sebagaimana yang diungkapkan oleh Agus Subroto adalah sebuah kerangka institusional untuk memperkuat otonomi Desa, karena secara substantif desentralisasi dan otonomi Desa bukan hanya masalah pembagian kewenangan antar level pemerintahan, melainkan sebagai upaya membawa negara lebih dekat dengan masyarakat. Pemerintah lokal tidak akan kuat dan otonomi tidak akan bermakna dan bermanfaat bagi masyarakat lokal jika tidak ditopang dengan transparansi, akuntabilitas, partisipasi dan responsivitas. ${ }^{6}$

\footnotetext{
${ }^{5}$ Muhadam labolo, Dinamika Politik dan Pemerintahan Lokal, Bogor : Ghalia Indonesia, 2015, h.82

${ }^{6}$ Agus Subroto, Akuntabilitas Pengelolaan Dana Desa (Studi Kasus Pengelolaan Alokasi Dana Desa Di Desa-Desa Dalam Wilayah Kecamatan Tlogomulyokabupaten Temanggung Tahun 20o8), Tesis Magister Sains Akuntansi, Semarang, UNDIP, 2009, h.23
} 
Pemberian ADD ini semakin memperlihatkan partisipasi Pemerintah Pusat dalam pembangunan Desa. Walaupun di dalam Undang-Undang otonomi daerah telah disebutkan bahwa pemeritah diarahkan untuk memberikan kewenangan kepada daerah untuk mengatur rumah tangganya sendiri, bukan berarti bahwa Pemerintah Pusat lepas tangan dari pengawasan pembangunan yang terdapat di daerah. Pembangunan merupakan proses perubahan yang berlangsung secara sadar, terencana dan berkelanjutan dengan sasaran utamanya adalah untuk meningkatkan kesejahteraan hidup masyarakat suatu bangsa. Indonesia saat ini sedang mengupayakan pembangunan yang berkesinambungan yang meliputi keseluruh kehidupan masyarakat, bangsa dan negara untuk melaksanakan tugas mewujudkan tujuan nasional yang tercantum dalam pembukaan Undang-Undang Dasar 1945.

ADD sepenuhnya ditangani secara swadaya oleh pemimpin daerah dan juga masyarakat langsung. Oleh sebab itu, peneliti lebih memilih meneliti mengenai program ini karena jika dana ini dikelola secara jujur dan baik, maka hasil pembangunan juga terlihat dengan jelas dan juga sebaliknya. Berdasarkan hal-hal yang telah dipaparkan sebelumnya, peneliti tertarik untuk meneliti lebih dalam tentang Analisis Implementasi Pengelolaan Keuangan Desa Dalam Alokasi Dana Desa (ADD) Desa Lobusiregar II Kecamatan Siborongborong Kabupaten Tapanuli Utara.

\section{B. Metode Penelitian}

Jenis penelitian ini termasuk dalam penelitian hukum yuridis-empiris, dengan bentuk deskriptif analitik yaitu dengan mengurai, menjelaskan, dan menggambarkan sesuai dengan permasalahan dari hasil penelitian dan dilakukan dengan mengadakan penelitian kepustakaan serta penelitian lapangan. Penelitian hukum yuridis-empiris dilakukan dengan meneliti secara langsung ke lokasi penelitian untuk melihat secara langsung penerapan perundang-undangan atau aturan hukum yang berkaitan dengan penegakan hukum, serta melakukan wawancara dengan beberapa responden yang dianggap memberikankan informasi mengenai pelaksanaan penegakan hukum tersebut. ${ }^{24}$

Adapun lokasi yang dipilih menunjang data yaitu:

a. Kantor Kepala Desa Lobusiregar II

b. Kantor BPD (BADAN PERMUSYAWARATAN DESA)

Untuk memperoleh data yang benar dan akurat dalam penelitian ini ditempuh prosedur (1) Studi Kepustakaan dan (2) Studi Lapangan. Berdasarkan uraian pendahuluan, landasan teori dan metode penelitian, peneliti mencoba memberikan gambaran umum mengenai kerangka pemecahan masalah sebagai berikut:

\footnotetext{
${ }^{24}$ Soerjono Soekanto, 1983, Pengantar Penelitian Hukum, Rineka Cipta, 


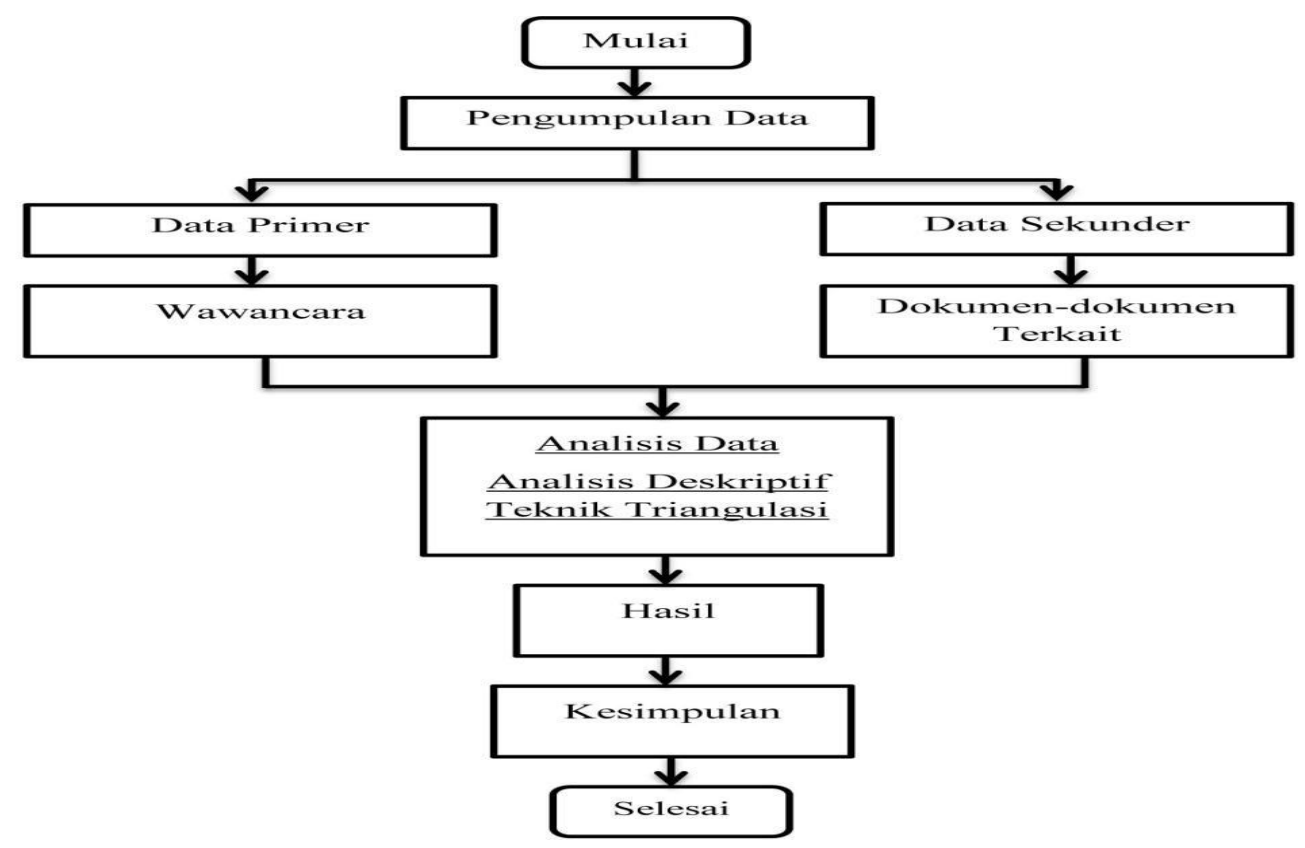

\section{Pembahasan Perencanaan}

Perencanaan merupakan tahap paling awal dalam pengelolaan Dana Desa. Tahap perencanaan erat kaitannya dengan kegiatan pembahasan mengenai RPJMDes dan juga RKPDes. Dalam pembuatan perencanaan RKPDes harus diselaraskan dengan program yang ditetapkan oleh pemerintah pusat. Pembahasan ini dilakukan didalam forum Musyawarah Perencanaan Pembangunan Desa (Musrenbagdes). Dalam musyawarah tersebut akan dihadiri oleh tokoh masyarakat, anggota BPD, Ketua RT/RW, Tokoh Agama, bahkan juga ada perwakilan dari pihak Kecamatan. Hal ini sesuai dengan penjelasan dari Sekretaris Desa, yaitu sebagai berikut: "Musrenbagdes adalah musyawarah yang diikuti oleh lembaga Desa, tokoh masyarakat, tokoh agama, PKK, karang taruna, kelompok tani dan disaksikan oleh pihak Kecamatan." 27

Pernyataan tersebut juga sudah sesuai dengan apa yang ada dilapangan, bahwa berdasrakan hasil wawancara dengan Ketua BPD, PLD Desa Lobusiregar II, serta Kaur Keuangan Desa Lobusiregar II. Hal ini menunjukkan bahwa perencanaan yang terkait musrenbagdes di Desa Lobusiregar II sudah sesuai prosedur yang ada. Prinsip terpenting dalam Musrenbagdes adalah adanya partisipasi dan transparansi dari pihak perangkat Desa. Desa Lobusiregar II juga telah mewujudkan salah satu asas pengelolaan keuangan Desa yakni prinsip partisipasi. Prinsip partisipasi tersebut dapat dilihat dari banyaknya elemen masyarakat yang turut hadir dan antusias dengan musrenbagdes yang diselenggarakan pihak Desa. Untuk tingkat partisipasi masyarakat sudah dapat dikatakan bagus karena diatas 80\%. Musrenbagdes adalah adanya partisipasi dan transparansi dari pihak perangkat Desa. Desa Lobusiregar II juga telah mewujudkan salah satu asas pengelolaan keuangan Desa yakni partisipasi. Prinsip partisipasi tersebut dapat dilihat dari banyaknya elemen masyarakat yang turut hadir dan antusias dengan musrenbagdes yang diselenggarakan pihak Desa. Pada Desa Lobusiregar II, setelah dilakukan musyawarah mengenai pembahasan RPJMDes dan RKPDesa, hasilnya akan dimasukkan ke dalam sistem keuangan Desa. Pemerintah Desa Lobusiregar II sendiri sudah menerapkan siskeudes pada tahun 2019. Pada menu Renstra Desa dapat dimasukkan Visi, Misi,

\footnotetext{
${ }^{27}$ Wawancara melalui telepon dengan Sekretaris Desa, Marnasib Siahaan Pada Tanggal 4 Juli 2020. 
Tujuan dan Sasaran yang ingin dicapai oleh pemerintah Desa Lobusiregar II pada tahun anggaran berjalan. Karena sudah tersistem, maka operator hanya perlu menuliskan pokok yang terdapat dalam sistem. Pada anggaran tahun 2019 lebih difokuskan pada pembangunan fisik seperti jalan pemukiman. Bahkan untuk saat ini, di beberapa Dusun, jalan Desa sudah beraspal dan dicor. Desa Lobusiregar II dalam menjalankan skala prioritas pembangunan dengan menganut pada asas keseimbangan dan juga pemerataan.

\section{Pelaksanaan}

Pelaksanaan dana Desa merupakan serangkaian kegiatan yang berkaitan dengan penerimaan serta pengeluaran untuk kegiatan yang akan dilaksanakan di suatu Desa. Tahap ini identik dengan proses realisasi anggaran. Dalam pelaksanaannya, kegiatan yang berhubungan dengan penggunaan dana Desa dilaksanakan oleh suatu tim Desa untuk melaksanakan pogram kegiatan di lapangan, tim tersebut lebih dikenal dengan istilah TPD atau Tim Pelaksana Desa Di Desa Lobusiregar II, Tim Pelaksana kegiatan terdiri dari lima sampai delapan anggota dimana terdapat jumlah satu dari unsur masyarakat. Tim tersebut akan dikoordinatori oleh Sekretaris Desa. Untuk dapat menjadi tim TPK harus mengetahui tentang pembangunan dan tata cara pembuatan Laporan Pertanggungjawaban (LPJ), karena tugas dari TPK sendiri adalah melaksanakan semua kegiatan fisik maupun non fisik dimana masing-masing program yang dilaksanakan tersebut wajib dipertanggungjawabkan dalam bentuk LPJ. Dalam rangka pelaksanaan pembangunan, semua penerimaan dan pengeluaran harus melalui rekening kas Desa (Permendagri No. 113 Tahun 2014). Dalam penggunaannya pun wajib disertai bukti baik tertulis maupun sejenisnya, agar dapat dipertanggungjawabkan pemakaiannya. Bukti pengeluaran di Desa Lobusiregar II akan dicatat dalam buku bank dan buku kas umum, yang wajib disertai dengan bukti pengeluaran seperti slip, nota, serta kwitansi. Kemudian, untuk pelaksanaan pembangunan yang didanai oleh Dana Desa harus melibatkan seluruh masyarakat dan dilaksanakan secara swakelola dengan menggunakan sumber daya atau bahan baku lokal dimana hal ini dimaksudkan untuk mengurangi angka pengangguran serta pemberian lapangan pekerjaan di Desa tersebut (UU No. 6 Tahun 2014). Namun pada kenyataannya, di Desa Lobusiregar II untuk pelaksanaan pembangunan Desa sudah diserahkan kepada pihak pemborong. Jadi dalam pelaksanaannya masyarakat tidak dilibatkan secara langsung.

\section{Penatausahaan}

Penatausahaan Keuangan Desa merupakan kegiatan yang berhubungan dengan pencatatan yang dilakukan oleh Bendahara Desa. Di Desa Lobusiregar II sendiri, kegiatan penatausahaan juga dilakukan oleh Kaur Keuangan, tetapi lebih spesifiknya ada operator khusus yang terkait dengan kegiatan penatausahaan. Bendahara Desa harus mencatat semua penerimaan dan pengeluaran terkait penggunaan Dana Desa Penatausahaan yang terkait dengan penerimaan dan pengeluran kas harus menggunakan buku kas umum, buku kas pembantu pajak dan buku bank. Namun untuk saat ini, kegiatan penatausahaan dilakukan secara terprogram dengan menggunakan sistem komputer. Berbeda dengan dulu yang masih secara manual. Dengan adanya sistem ini maka akan mempermudah dalam kegiatan penatausahaan. Penatausahaan keuangan dalam siskeudes terdiri atas buku kas umum, buku pembantu kas tunai, buku pembantu bank, buku kas pembantu kegiatan, buku kas pembantu pajak, buku kas pembantu panjar.

\section{Pelaporan Dan Pertanggungjawaban}

Pelaporan adalah bentuk pertanggungjawaban atas hasil apa saja yang sudah terealisasi atas program atau kegiatan yang sudah dicanangkan atau dibentuk sebelumnya selama kurun waktu tertentu, biasanya satu periode. Laporan juga menjadi salah satu sumber informasi 
mengenai kegiatan yang sudah berlangsung. Pada tahap ini, Kepala Desa harus menyampaikan laporan realisasi pelaksanaan APBDes kepada Bupati/Walikota. Laporan tersebut berupa laporan semester pertama dan laporan semester akhir tahun. Laporan semester pertama berupa laporan realisasi APBDes sedang laporan semester akhir disampaikan paling lambat pada akhir bulan Januari tahun berikutnya (Permendagri No. 113 Tahun 2014). Jenis pelaporan yang dilakukan oleh pemerintah Desa Lobusiregar II dalam proses penggunaan Dana Desa adalah dalam bentuk Laporan Pertanggungjawaban (LPJ). Jadi untuk setiap program masingmasing wajib ada LPJ nya. Pertanggungjawaban keuangan Desa merupakan tahap akhir pengelolaan keuangan Desa setelah tahap pelaporan. Pertanggungjawaban tersebut disampaikan kepada Bupati/Walikota (Permendagri No. 113 Tahun 2014). Hal tersebut sesuai dengan hasil wawancara dengan Kaur Keuangan Desa Lobusiregar II Friska Sitompul sebagai berikut: “......... Alurnya itu Kecamatan kemudian ke Kabupaten, nanti dinilai misal ada sesuatu kita dipanggil misal ada temuan seperti itu.” (Kaur Keuangan Desa Lobusiregar II, o2 Juli 2020).

Jenis laporan keuangan Desa yang terdapat dalam siskeudes terdiri atas laporan realisasi APBDesa, laporan realisasi anggaran, lapora realisasi anggaran Desa perkegiatan, laporan realisasi anggaran bulanan, triwulan, semesteran, laporan realisasi APBDes semesteran, laporan kekayaan milik Desa, laporan realisasi APBDes per sumberdana $1 \mathrm{a}$ dan $1 \mathrm{~b}$, laporan realisasi penggunaan dana Desa serta laporan penyerapan Dana Desa. ${ }^{28}$

\section{Prioritas Penggunaan Dana Desa.}

Dana Desa sejatinya memiliki tujuan untuk meningkatkan kesejahteraan masyarakat serta pemerataan pembangunan yang ada di suatu Desa. Dengan pemerataan pembangunan yang ada di suatu Desa, diharapkan dapat meningkatkan pelayanan publik, meningkatkan perekonomian disuatu Desa serta dapat mengurangi kesenjangan antara Desa satu dengan Desa yang lainnya.

Secara umum terdapat empat bidang yang wajib dilakukan terkait penggunaan dana Desa, yakni meliputi bidang pemerintahan, bidang pemberdayaan, bidang pembangunan serta kemasyarakatan. Namun Dana Desa lebih diprioritaskan untuk bidang pembangunan dan pemberdayaan masyarakat. Sesuai dengan peraturan diatas, bahwa di Desa Lobusiregar II penggunaan Dana Desa juga lebih diprioritaskan untuk bidang pembangunan dan pemberdayaan masyarakat. Hal ini dapat dilihat pada Anggaran Pendapatan dan Belaja Desa Lobusiregar II pada tahun 2019 yang ditempel disetiap sudut jalan di Desa Lobusiregar II. Pada banner tersebut dapat terlihat bahwa dana Desa yang berjumlah $\mathrm{Rp}$ 1.040.229.000,00 diperuntukkan untuk 2 bidang utama tersebut. Berikut adalah laporan APBDesa tahun 2019 di Desa Lobusiregar II: ${ }^{29}$

\section{1) Bidang Pelaksanaan Pembangunan Desa}

Penggunaan dana Desa pada bidang pembangunan memiliki beberapa tujuan. Pengalokasian dana tersebut bertujuan untuk meningkatkan kesejahteraan dan kualitas hidup, mengurangi angka kemiskinan di suatu Desa. Penanggulangan kemiskinan tersebut dapat dilaksanakan dengan memenuhi kebutuhan dasar, pembangunan sarana prasarana, pengembangan ekonomi lokal yang potensial serta pengelolaan sumber daya alam secara berkelanjutan.

Bidang Pembangunan sangat identik dengan pembuatan gedung, jalan, jembatan, rumah atau pembangunan fisik lain yang dapat dinikmati secara langsung oleh masyarakat. Dengan adanya pembangunan tersebut diharapkan dapat membawa perubahan ke arah yang lebih baik

\footnotetext{
${ }^{28}$ Wawancara dengan kaur keuangan,Friska Sitompul,Melalui telepon,pada tanggal 2 Juli,2020.

${ }^{29}$ Data Anggaran Dana Desa Lobusiregar II Tahun 2019.
} 
demi mencapai tujuan yang ingin diraih. Pelaksanaan bidang pembangunan yang ada di Desa Lobusiregar II menjadi salah satu prioritas penggunaan dana Desa pada tahun 2019. Pembangunan tersebut meliputi penyuluhan dan pelatihan bagi masyaarakat,penyelenggaraan posyandu,pemeilharaan jalan Desa, pembangunan/rehabilitasi/peningkatan/pengerasan jalan Desa pembangunan rehabilitasi/peningkatan/pengerasan lingkungan F,pembuatan dan pengelolaan jaringan/instalasi komunikasi dan informasi. Kegiatan-kegiatan pembangunan yang dibiayai dari dana Desa yang ada di Desa Lobusiregar II pada tahun anggaran 2019 meliputi:

\section{a. Penyuluhan dan Pelatihan Pendidikan Bagi Masyarakat}

Dalam suatu Desa sangat diperlukan memberikan edukasi kepada masyarakat,pelatihan maupun penyuluhan bagi masyarakat Desa,yang dapat diberikan adalah memberikan pemahaman tentang apa apa saja hak dan kewajiban masyarakat di dalam suatu Desa.Seperti dapat dilihat dalam Desa Lobusiregar II,bahwa sangat penting nya diberikan pelatihan,penyuluhan,dan pendidikan masyarakat seperti tentang kajian-kajian Hukum yang berlaku di Indonesia maupun memberikan pelatihan bagi masyarakat tentang struktur perangkat Desa maupun menjelaskan tentang apa peran dan fungsi daripada Kepala Desa,Sekretaris Desa,kepala urusan keuangan Desa, kepala urusan tata usaha Desa,kepala urusan,kepala urusan perencanaan desa dan tugas dan fungsi daripada BPD (BADAN PERMUSYAWARATAN DESA). Dimana dapat memberikan pemahaman yang lebih akurat kepada masyarakat,dan masyrakat pun dapat mengerti apa tugas dan fungsi daripada aparatur Desa tersebut dengan cara tersebut masyarakat Desa akan lebih bijak dalam memahami tentang tugas dan fungsi aparatur Desa.

b. Penyelenggaraan Posyandu

Desa telah menyediakan kepada masyarakat khusunya agar mendaftarkan dan membawa anak nya ke posyandu yang telah disediakan,seperti di Desa Lobusiregar II,masyarakat Lobusiregar II sudah lebih praktis dalam melakukan imunisasi kepada anak-anak nya dangan telah diberikan pelayanan seperti posyandu akan meringankan biaya pengobatan dan imunasasi bagi anak khususnya di daerah Lobusiregar II.

\section{c. Pemeliharaan Jalan Desa}

Pemeliharaan jalan Desa Lobusiregar II juga menjadi prioritas di bidang pembangunan pada Desa Lobusiregar II tahun 2019. Berdasarkan Permendesa No. 19 Tahun 2017 tentang penetapan prioritas penggunaan dana desa tahun 2018 bagian pengadaan, pembangunan, pengembangan dan pemeliharaan sarana prasaran ekonomi Desa salah satunya dipergunakan untuk pemeliharaan atau perbaikan jalan Desa. Berdasarkan APBDes Desa Lobusireagr II, berarti penggunaan skala prioritas tersebut sudah sesuai dengan peraturan yang berlaku. Pemeliharaan jalan ini dilakukan di beberapa dusun yang ada di Desa Lobusiregar II. Desa Lobusiregar II sendiri memiliki 8 (Delapan) yang harus diperhatikan pemeliharaan jalannya. Tujuan dilakukannya pemeliharaan jalan ini agar menambah nilai keindahan dan juga agar tetap terawat.

\section{d. Pembangunan/Rehabilitas/Peningkatan/Pengerasan Jalan Desa}

Rehabilitas/Peningkatan jalan aspal menjadi salah satu program yang ada di Desa Lobusiregar II untuk tahun anggaran 2019. Program tersebut sudah sesuai dengan Permendes No. 19 Tahun 2017 tentang penetapan prioritas penggunaan dana desa tahun 2018. Pengadaan, pembangunan, pengembangan dan pemeliharaan sarana prasarana transportasi pada Permendesa No. 19 Tahun 2017 antara lain digunakan 
untuk jalan pemukiman dan juga jalan poros desa. Program pembangunan rehap jalan yang didanai dari dana desa, yang dilakukan oleh Desa Lobusiregar II menjadi program yang terealisasi pada tahun 2019. Pembangunan rehap jalan ini mencakup semua Dusun mulai dari Dusun 1,2,3,4,5,6,7,8. Dalam melakukan program ini, pihak Desa mengacu pada asas pemerataan dan juga keseimbangan. Tujuan dari perbaikan jalan sendiri adalah untuk memperlancar transportasi masyarakat sekitar untuk menjalankan aktivitas sehariharinya. Dampak dari adanya perbaikan jalan ini sudah dirasakan oleh masyarakat Desa Lobusiregar, mereka merasa terbantu dan sangat nyaman untuk melewati jalan tersebut.

e. Pembangunan/Rehabilitasi/Peningkatan/Pengerasan Jalan Dusun VI

Pembangunan jalan Desa khususnya dusun VI menjadi salah satu program khusus pembangunan yang ada di Desa Lobusiregar II. Pembangunan jalan yang bernilai Rp111.983.420,oo sudah dikerjakan tepatnya di Dusun VI Desa Lobusiregar II. Berdasarkan peraturan,berarti pemerintah Desa Lobusiregar II sudah melaksanakan pembangunan berdasarkan Permendes No. 19 Tahun 2017 terkait pengadaan, pembangunan, pemanfaatan dan pemeliharaan sarana dan prasarana Desa yakni salah satunya untuk pengerasan jalan Dusun VII Desa Lobusiregar II. Jalan ini berlokasi di dekat Dusun IV. Diharapkan dengan dilakukannya pengerasan di Dusun ini, warga sekitar yang ingin menggunakan jalan tersebut dapat dilalui dengan nyaman. Tujuan dikukannya pengerasan jalan tersebut adalah dapat mempermudah prasaran khususnya transportasi di Desa Lobusiregar II.

\section{f. Pembuatan Dan Pengelolaan Jaringan/Instalasi Komunikasi Dan} Informasi.

Program pemberdayaan yang terkait IT juga sudah sesuai dengan Permendagri No. 19 Tahun 2017. Program ini berupa pemasangan Wifi, namun penggunaan dana Desa hanya boleh digunakan untuk pemasangan saja, untuk biaya perbulan tidak boleh dianggarkan dari dana Desa. Selain itu belum semua lapisan masyarakat Desa Lobusireagar II merasakan dampak dari fasilitas Wifi ini.

\section{2) Bidang Pembinaan Masyarakat}

\section{a. Penyelenggarann Festival Kesenian,Adat/Kebudayaan,dan Keagamaan}

Festival merupakan sarana komunikasi yang penting untuk membangun, memberdayakan, dan pengakuan suatu identitas budaya. Karenanya, sebagai sebuah sarana komunikasi, maka sudah selayaknya sebuah event festival direncanakan melalui proses perencanaan strategis komunikasi agar dapat berjalan dengan efektif.

Komunikasi merupakan sarana untuk mensosialisasikan nilai-nilai budaya kepada masyarakatnya. Komunikasi dapat menjadi sarana transmisi budaya dari satu generasi ke generasi berikutnya. Komunikasi menciptakan, atau membuat segala kebimbangan menjadi lebih pasti, dan bagaimanapun juga 'budaya' suatu kelompok dalam masyarakat menjadi ada dan terus ada karena mereka memiliki sejarah dan tradisi yang panjang yang diturunkan dari satu generasi ke generasi lainnya.

Pelestarian budaya adat istiadat adalah upaya untuk mempertahankan nilai-nilai seni budaya dan adat tersendiri, nilai budaya dan adat dengan mengembangkan perwujudan yang bersifat dinamis, luwes dan selektif, serta menyesuaikan dengan situasi dan kondisi yang selalu berubah dan berkembang. Salah satu tujuan diadakannya pelestarian budaya adalah juga untuk melakukan revitalisasi budaya.Sama halnya seperti di Desa Lobusiregar II,dapat dilihat bahwa di Desa tersebut nillai-nilai adat istiadat dan budaya yang terkait dengan Desa Lobusiregar II masih dijaga dengan baik,tokoh masyarakat yang ada di Desa Lobusireagar II 
masih tetap memegang teguh ideologi adat istiadat dan kebudayaannya, yang pembelajaran maupun penerapannya terhadap adat istiadat dan kebudayaan di Desa Lobusiregar II,masih tetap diturunkan kepada regenerasi yang akan mendatang khususnya untuk masyarakat Desa Lobusiregar II.

\section{b. Pembinaan Karang Taruna/Klub Kepemudaan/Olahraga Tingkat Desa.}

Ada beragam tugas yang diemban oleh organisasi para pemuda ini. Namun yang paling menonjol tugasnya adalah menjaga kesejahteraan sosial dalam lingkungan yang dihuninya. Pengertian kesejahteraan sosial sendiri adalah terpenuhinya kebutuhanwarga negara yang meliputi kebutuhan materi, sosial dan spiritual serta hal lain yang penting sebagai penunjang kualitas hidup warga. Hingga, membuat warga bisa berkehidupan layak dan tidak serba kekurangan. Karena kita adalah makhluk sosial maka sudah sepantasnya kita saling membantu antar sesama. Organisasi ini didirikan dengan tujuan membantu masalah-masalah sosial yang terjadi di sekitarnya. Adapun tugas daripada karang taruna di Desa Lobusiregar II adalah :

1. Menciptakan rasa tanggung jawab kepada sesama makhluk sosial yang tak bernasib baik dari kita. Juga mengatasi berbagai masalah-masalah sosial.

2. Meningkatkan kualitas para pemuda dan pemudi lewat aktivitas sosial yang dapat membantu kepribadian mereka menjadi lebih baik.

3. Menyelenggarakan berbagai acara yang bertujuan untuk membangun karakter jiwa muda yang membanggakan.

4. Sebagai penyelenggara kegiatan peningkatan kewirausahaan bagi para pemuda agar dalam kehidupannya lebih mengerti meski latar belakang hidup yang tidak mendukung.

5. $\quad$ Menumbuhkan semangat kebersamaan, sosialisasi yang kuat antara satu warga dengan warga yang lain.

\section{Pembinaan PKK.}

Pemberdayaan Kesejahteraan Keluarga (PKK) sebagai gerakan pembangunan masyarakat bermula dari seminar Home Economic di Bogor pada 1957. Sebagai tindak lanjut dari seminar tersebut, pada 1961 panitia penyusunan tata susunan pelajaran pada Pendidikan Kesejahteraan Keluarga (PKK), Kementerian Pendidikan bersama kementerian-kementerian lainnya menyusun 10 segi kehidupan keluarga. Gerakan PKK dimasyarakatkan berawal dari kepedulian istri gubernur Jawa Tengah pada 1967 (ibu Isriati Moenadi) setelah melihat keadaan masyarakat yang menderita busung lapar.

Upaya untuk meningkatkan kesejahteraan keluarga melalui 10 segi pokok keluarga dengan membentuk Tim Penggerak PKK di semua tingkatan, yang keanggotaan timnya secara relawan dan terdiri dari tokoh/pemuka masyarakat, para isteri kepala dinas/jawatan dan isteri kepala daerah sampai dengan tingkat desa dan kelurahan yang kegiatannya didukung dengan anggaran pendapatan dan belanja daerah

Gerakan PKK bertujuan memberdayakan keluarga untuk meningkatkan kesejahteraan menuju terwujudnya keluarga yang beriman dan bertaqwa kepada tuhan yang maha esa, berakhlak mulia dan berbudi luhur, sehat sejahtera, maju dan mandiri, kesetaraan dan keadilan gender serta kesadaran hukum dan lingkungan.

Tim Penggerak PKK berada di tingkat pusat sampai dengan Desa/kelurahan, PKK dikelola dan digerakkan oleh Tim Penggerak PKK yang diketuai oleh isteri Pimpinan Daerah (Gubernur, Bupati/Walikota, Camat, Kepala Desa/Lurah), secara fungsional. Dapat dikemukakan bahwa kunci berkembangnya program dan kegiatan PKK, justru ada peran nyata diwujudkan oleh istri Pimpinan Daerah.

Apabila dilihat di Desa Lobusiregar II,Gerakan ibu PKK di Desa tersebut dapat dikatakan sangat efektif,dimana PKK di Desa Lobusiregar II dapat membuat kegiatan-kegiatan 
yang positif yang bermakna untuk masyrakat khususnya di Desa tersebut. Serta dapat berperan aktif dalam kegitan yang diselenggarakan oleh pemerintah Desa Lobusiregar II.

\section{d. Pelatihan Pembinaan Lembaga Kemasyarakatan.}

Kegiatan pembinaan lembaga kemasyarakatan merupakan upaya pembinaan dari pemerintah Desa untuk meningkatkan kinerja lembaga di bawahnya agar dapat bekerja sesuai dengan yang diharapkan dan membantu pemerintah dalam memajukan Desa. Lembagalembaga tersebut diantaranya seperti RT, RW, karang taruna, PKK, keamanan, dan lain-lain. Adapun bentuk pembinaan lembaga kemasyarakatan ini dapat berupa pelatihan, rapat koordinasi, dan peningkatan sarana dan prasarana lembaga.

Kegiatan yang telah dilakukan di Desa Lobusiregar II,dalam pelatihan pembinaan lembaga kemasyarakatan adalah,dapat menghidupkan kembali lembaga-lembaga yang terkait di dalamn pemerintah Desa tersebut,dengan membuat berbagai kegiatan yang dapat memajukan masyarakat dan Desa Lobusiregar II.

\section{3) Bidang Pemberdayaan Masyarakat}

\section{a. Peningkatan Kapasitas Kepala Desa}

Kepala Desa mempunyai tugas berat dalam menjalankan roda pemerintahan di tingkat Desa. Saat ini, Desa dituntut mampu mengelola anggaran pemerintah yang nilainya cukup besar, Sehingga Kades dan mesti lebih meningkatkan kapasitas Sumber Daya Manusia (SDM) dengan berbagai kegiatan pelatihan ataupun bimbingan teknis (Bimtek). Termasuk kegiatan peningkatan SDM aparatur Desa ini dinilai sangat membantu dalam peningkatan kapasitas dan kemampuan Kepala Desa.

Dalam beberapa kegiatan yang telah dilakukan dalam peningkatan kapasitas Kepala Desa baik dalam BIMTEK, Kepala Desa Lobusiregar II telah menjalankan mengikuti kegiatan tersebut,yang dapat bertujuan dalam meningkatkan SDM Kepala Desa Lobusiregar II,dalam menjalankan tugasnya dalam pemerintahan Desa.

\section{b. Peningkatan Kapastias Perangkat Desa.}

Undang-undang Nomor 6 Tahun 2014 tentang Desa menjadi langkah utama dalam mewujudkan kebijakan pemerintah sebagaimana disebutkan diatas dalam rangka meningkatkan kesejahteraan maupun layanan yang akan diterima oleh masyarakat jika memang undang-undang tersebut diterapkan dengan sungguh-sungguh. Hal ini disebabkan karena dengan diakuinya Desa sebagai sebuah daerah otonom menjadikan Desa memiliki peran utama dalam mengelola, memberdayakan dan memajukan sumber daya yang tersedia, baik sumber daya alam maupun sumber daya manusia. Sehingga pada akhirnya mampu menggerakkan roda pembangunan yang harus diiringi kesadaran akan pemahaman spirit otonomi bagi seluruh penggerak warga desa dan kapasitas perangkat juga masyarakat dalam memahami tata kelola pemerintahan.

Perangkat Desa Lobusiregar II mempunyai tugas dan tanggung jawab dalam menjalankan pemerintahan di tingkat Desa. Dalam situasi ini, Perangkat Desa dituntut mampu mengelola anggaran pemerintah yang nilainya cukup besar dengan mengelola dengan sebaik mungkin dalam pemerintahan Desa, Sehingga perangkat Desa Lobusiregar II mesti lebih meningkatkan kapasitas Sumber Daya Manusia (SDM) dengan berbagai kegiatan pelatihan ataupun bimbingan teknis (Bimtek). Terkhusus kegiatan peningkatan SDM perangkat Desa ini, dinilai sangat membantu dalam peningkatan kapasitas dan akuntabilitas daripada perangkat Desa Lobusiregar II.

\section{c. Peningkatan Kapasitas BPD}

Pemerintah Daerah Kabupaten Tapanuli Utara Dinas Pemberdayaan Masyarakat Desa, Pemberdayaan Perempuan dan Perlindungan Anak (DPMDP3A). Pada Bimtek tersebut,bahwa 
Bimtek BPD bertujuan untuk memantapkan pelaksanaan tugas-tugas BPD sebagai mitra pemerintah dalam menyelenggarakan pemerintahan. Selain itu, BPD memiliki peran strategis bagi jalannya pemerintahan Desa. Sehingga, dapat meningkatkan kapasitas dan fungsi BPD sebagai pengawasan penyelenggaraan pemerintahan pada tingkat Desa.

Jelas, bahwa BPD adalah mitra pemerintah Desa yang harus bisa bersinergi dengan Kepala Desa dan aparatnya. Olehnya, untuk dapat bersinergi dibutuhkan peningkatan kapasitas sebagai lembaga masyarakat yang ada di Desa. BPD merupakan salah satu wadah atau tempat menyalurkan aspirasi bagi warga Desa. Jika ada aspirasi warga, BPD harus segera menindaklanjuti demi menyelesaikan persoalan masyarakat yang ada di desa.

\section{d. Pembentukan BUMDes (Persiapan Dan Pembentukan BUMDes).}

BUMDes merupakan bentuk penguatan terhadap lembaga-lembaga ekonomi Desa serta merupakan alat pendayagunaan ekonomi lokal dengan berbagai ragam jenis potensi yang ada di Desa. Pendirian badan usaha Desa pasti memiliki tujuan, tidak terkecuali dengan pembentukan BUMDes. Dalam penelitian ini setelah sebelumnya kita membahas tentang Pengertian BUMDes sekarang kita harus memahami maksud dan tujuan pembentukan bumdes. BUMDes pada dasarnya merupakan bentuk konsolidasi atau penguatan terhadap lembaga-lembaga ekonomi Desa dan merupakan instrumen pendayagunaan ekonomi lokal dengan berbagai ragam jenis potensi, yang bertujuan untuk peningkatan kesejahteraan ekonomi masyarakat Desa melalui pengembangan usaha ekonomi.

\section{Tujuan Pembentukan Bumdes}

1. Meningkatkan perekonomian Desa.

2. Mengoptimalkan aset Desa agar bermanfaat untuk kesejahteraan Desa.

3. Meningkatkan usaha masyarakat dalam pengelolaaan potensi ekonomi Desa.

4. Mengembangkan rencana kerjasama usaha antar Desa dan/atau dengan pihak ketiga.

5. Menciptakan peluang dan jaringan pasar yang mendukung kebutuhan layanan umum warga.

6. Membuka lapangan kerja.

7. Meningkatkan kesejahteraan masyarakat melalui perbaikan pelayanan umum, pertumbuhan dan pemerataan ekonomi Desa.

8. Meningkatkan pendapatan masyarakat Desa dan PADesa.

Akan tetapi apabila dilihat dalam Desa Lobusiregar II,masih ada sedikit kekurangankekurangan yang harus terpenuhi khusus nya dalam BUMDes, yang dimana BUMDes dikenal dapat memajukan ekonomi kreatif Desa.

\section{4) Dampak Kesejahteraan Masyarakat Lobusiregar II.}

Kesejahteraan masyarakat sangat penting, khususnya penerapannya di Desa Lobusiregar II. Dengan hadirnya anggaran dana Desa (ADD) pemerintah Desa Lobusiregar II pada tahun 2019,pemerintah Desa harus bijaksana dan koperatif dalam menjalankan tugas serta efektif dalam penggunaan dana Desa tersebut,keterbukaan pemerintah Desa Lobusiregar II kepada masyarakatnya dalam pengelolaan anggaran dana Desa (ADD) harus transparan.Sehingga masyarakat dapat mengetahui dan merasakan apa yang telah diberikan pemerintah pusat kepada pemerintahan daerah khusunya daerah otonom yaitu Desa,sehingga masyarakat mendapatkan kata kesejahteraan tersebut.

Adapun dampak dari anggaran dana Desa Lobusiregar II dapat dikelompokkan menjadi sektor pendidikan, sektor kesehatan,sektor eokonomi dan sektor pertanian.

a. Sektor Pendidikan 
Dari sektor pendidikan, berdasarkan hasil penelitian bahwa pemberian fasilitas bermain serta perawatan pembangunan PAUD sudah memberikan dampak bagi masyarakat. Untuk saat ini fasilitas yang ada disekolahan tersebut sudah dikatan lengkap, sehingga akan lebih nyaman dan senang untuk anak-anak bermain dan belajar di sekolahan tersebut.Dengan hadirnya PAUD yang ada di Desa Lobusiregar II,pemerintah Desa mempergunakan masyarakatnya sendiri yang telah mempunyai gelar terkhusus jurusan keguruan dalam proses mengajar, sehingga para siswa yang ada di PAUD tersebut akan lebih nyaman,dan akan lebih terbuka pada saat proses belajar mengajar.

b. Sektor kesehatan

Bidang kesehatan juga menjadi prioritas penting di dalam pembangunan yang didanai dari dana Desa dari sisi kesehatan, sudah dirasakan dampaknya oleh masyarakat Lobusiregar II dengan tersedianya Posyandu balita dan Posyandu Lansia yang telah disediakan oleh Pemerintah Desa Lobusiregar II. Masyarakat sangat terbantu dengan adanya Posyandu balita dan Posyandu Lansia tersebut,sehingga apabila masyarakat memerlukan sesuatu dalam prospek kesehatan,pemerintah Desa Lobusiregar II telah menyediakan apa-apa saja yang dibutuhkan masyarakatnya.

c. Sektor Ekonomi

Dari sisi ekonomi salah satunya adalah pengelolaan dari BUMDes yaitu pembuatan Unit Usaha Desa "Parade" dengan meneyediakan Pupuk dan Gas LPG bersubsidi, yang diperuntukkan bagi petani maupun masyarakat Desa. Namun untuk dapat menggunakan tersebut, masyarakat diharuskan melengkapi persyaratan-persyaratan yang harus dilengkapi dan dikhususkan bagi keluarga yang tidak mampu, sehingga dapat menggunakan apa yang disediakan oleh unit Desa Parade. Berdasarkan hasil penelitian saya masyarakat Desa Lobusiregar II sangat terbantu dengan hadirnya unit usaha Desa Parade Tersebut.Sehingga memudahkan dan meringan kepada masyarakat dalam memenuhi kebetuhan nya pada saat bertani maupun yang lainnya, dengan harga yang dapat dikategorikan terjangkau oleh masyarakat Desa Lobusiregar II.

d. Sektor Pertanian

Dari sektor pertanian, masyarakat mendapat bantuan dari segi barang yang telah disediakan oleh pemerinmtah Desa Lobusiregar II. Bantuan sarana prasarana yang diberikan dari dana Desa Lobusiregar II berupa alat pemotong rumput, semporotan hama, dan juga pembasmi rumput.Pemberian sarana prasarana pertanian dimana para petani sangat merasa terbantu dengan adanya dana Desa ini. Mereka sangat merasakan dampak dari adanya mesin pembasmi hama, mesin pemotong rumput dan lain sebagainya.

\section{Kesimpulan}

Pengelolaan keuangan yang dimulai dari tahap perencanaan, pelaksanaan, penatausahaan, pelaporan dan pertanggungjawaban yang ada di Desa Lobusiregar II secara umum sudah sesuai dengan Permendagri No. 113 Tahun 2014. Bahkan untuk saat ini pemerintah Desa Lobusiregar II sudah menggunakan Sistem Keuangan Desa (Siskeudes) dalam tahap perencanaan, penganggaran, penatausahaan dan pelaporan. Dengan menggunakan sistem ini maka akuntabilitas pengelolaan keuangan Desa akan dapat terwujud.

Secara umum pengelolaan dana Desa diperuntukkan untuk bidang pelaksanaan pembangunan dan pemberdayaan masyarakat. Hal tersebut sudah sesuai dengan Permendesa No. 19 Tahun 2017 tentang penetapan skala prioritas penggunaan dana Desa tahun 2019. Dari 
sisi pendidikan, kesehatan dan pertanian dampaknya sudah dirasakan oleh masyarakat, sedangkan dari sisi ekonomi dampaknya belum sepenuhnya dirasakan oleh masyarakat Desa Lobusiregar II.

\section{Daftar Pustaka}

Ateng Syafrudin, "Republik Desa, Pergulatan Hukum Tradisional Dan Hukum Modern Dalam Desain Otonomi Desa", Bandung: Alumni, 2010.

B. N. Marbun, Otonomi Daerah 1945-2010 Proses E Realita, Jakarta: Sinar Harapan, 2010.

Abdul Halim, M.Syam Kusufi, Teori, Konsep dan Aplikasi Akuntansi Sektor Publik, Jakarta : Salemba Empat, 2016.

Muhadam labolo, Dinamika Politik dan Pemerintahan Lokal, Bogor : Ghalia Indonesia, 2015.

Nurman, Strategi Pembangunan Daerah, Jakarta : Rajawali Pers, 2015, h.226

Muhadam labolo, Dinamika Politik dan Pemerintahan Lokal, Bogor : Ghalia Indonesia, 2015.

Said Zainal Abidin, Kebijakan Publik, Jakarta: Salemba Humanika,2012

Soerjono Soekanto, 1983, Pengantar Penelitian Hukum, Rineka Cipta, UU No. 6 Tahun 2014 tentang desa.

Permendagri No 113 Tahun 2014 tentang pengelolaan keuangan Desa

Daru Wisakti, implementasi kebijakan alokasi dana desa di wilayah kecamatan geyer kabupaten grobogan. (Semarang: Tesis, Pascasarjana Universitas Diponegoro 2015)

Agus Subroto, Akuntabilitas Pengelolaan Dana Desa, Studi Kasus Pengelolaan Alokasi Dana Desa Di Desa-Desa Dalam Wilayah Kecamatan Tlogomulyokabupaten Temanggung Tahun 2008 ), Tesis Magister Sains Akuntansi, Semarang, UNDIP, 2009.

Yuliansayah, Akuntansi Desa Dokumen anggaran dana desa (ADD) Lobusiregar II Tahun 2019

Nurman, Strategi Pembangunan Daerah, Jakarta : Rajawali Pers, 2015, h.226

Yuliansayah, Akuntansi Desa, Jakarta : Salemba Empat, 2016. 10 April 2020.

Data Desa Lobusiregar II.

Wawancara melalui telepon dengan Sekretaris Desa,Marnasib Siahaan Pada Tanggal 4 Juli 2020.

Wawancara dengan kaur keuangan,Friska Sitompul,Melalui telepon,pada tanggal 2 Juli,2020.

Data Anggaran Dana Desa Lobusiregar II Tahun 2019.

\section{Internet}

http://www.bpkp.depkeu.go.id/public/upload/unit/sakd/files/Juklakbimkonkeudesa.p df. diakses tanggal 10 April 2020.

http://www.bpkp.depkeu.go.id/public/upload/unit/sakd/files/Juklakbimkonkeudesa.p df. diakses tanggal 10 April 2019. 